\title{
Hasil Tanaman pada Beberapa Model Tumpang Sari Kentang (Solanum tuberosum L) dan Kacang Faba (Vicia faba L) di Salaran Getsan Jawa Tengah (1500-1700 mdpl)
}

Theresa Vinata Anui ${ }^{1 *}$, Dina Rotua Valentina Banjarnahor ${ }^{1}$

${ }^{1}$ Departemen Agroteknologi, Fakultas Pertanian dan Bisnis, Universitas Kristen Satya Wacana

\begin{tabular}{l}
\hline \multicolumn{1}{c}{ ARTIKEL INFO } \\
\hline Sejarah artikel \\
Diterima 20/11/2020 \\
Diterima dalam bentuk revisi 01/12/2020 \\
Diterima dan disetujui 07/12/2020 \\
Tersedia online 23/12/2020 \\
\hline Kata kunci \\
Tumpangsari \\
Kentang \\
Kacang faba \\
Kacang Dieng \\
\hline
\end{tabular}

\begin{abstract}
ABSTRAK
Meningkatnya pengetahuan petani tentang dampak buruk yang berkepanjangan penggunaan pupuk kimia sintetis menjadikan praktik tumpangsari dengan tanaman legum semakin digemari. Penelitian terdahulu menyebutkan tumpangsari dengan tanaman legum dapat menjadi pupuk nitrogen organik. Pada petani kentang, tanaman legum yang syarat hidupnya sama dengan syarat hidup tanaman kentang adalah kacang faba. Penelitian ini bertujuan untuk melihat hasil tanaman pada beberapa model tumpangsari kentang dan kacang faba. Penelitian ini dilaksanakan pada bulan Februari 2020 sampai bulan Mei 2020, di Kebun Percobaan Fakultas Pertanian dan Bisnis UKSW Salaran, Kecamatan Getasan, Kabupaten Semarang (ketinggian 1500-1700 mdpl). Perlakuan dalam penelitian ini yaitu kentang dan kacang faba ditanam pada bedengan bermulsa dengan rasio 2:1 (P1), kacang faba ditanam pada setiap sela dua bedengan kentang bermulsa (P2), kacang faba ditanam pada setiap sela bedengan kentang bermulsa (P3), tanaman kentang dengan sistem monokultur yang ditanam pada bedengan bermulsa (P4) dan tanaman kacang faba yang ditanam pada satu bedengan persegi empat tanpa mulsa (P5). Hasil penelitian menunjukkan hasil tanaman kentang tertinggi pada $\mathrm{P}$ tetapi hasilnya tidak memenuhi standar varietas granola, serta tanaman kacang faba tidak memberikan hasil. Hasil tanaman kentang demikian karena pada saat pembentukan umbi terjadi serangan penyakit yang menyerang daun sehingga alat fotosintesis terganggu. Hasil kacang faba demikian karena pengaruh suhu lingkungan yang tidak mendukung pembentukan polong.
\end{abstract}




\section{ABSTRACT}

Increasing knowledge of farmers about the prolonged adverse effects of using synthetic chemical fertilizers has made the practice of intercropping with legume crops increasingly popular. Previous research has stated that intercropping with legume plants can be used as organic nitrogen fertilizer. For potato farmers, legume plants whose life requirements are the same as those for potato plants are faba beans. The aim of this study was to examine crop yields in several models of intercropping potatoes and faba beans. This research was conducted from February 2020 to May 2020, at the SWCU Agriculture and Business Faculty Experimental Garden Salaran, Getasan District, Semarang Regency (altitude 1500-1700 masl). The treatments in this study were potatoes and faba beans planted in mulched potato beds with a ratio of 2: 1 (P1), faba beans were

\section{PENDAHULUAN}

Tanaman kentang (Solanum tuberosum

L) merupakan produk hortikultura yang permintaannya kian meningkat seiring bertambahnya jumlah penduduk, jika dikembangkan memiliki potensi dan peluang yang besar untuk perekonomian negara (Samadi, 2007). Jika dilihat dari nutrisinya umbi kentang mengandung sedikit lemak dan kolesterol, karbodhidrat, sodium, serat, protein, vitamin $\mathrm{C}$, kalsium zat besi dan vitamin $\mathrm{B} 6$ yang cukup tinggi (Kolasa, 1993). dengan kandungan yang sedemikan rupa kentang dapat menjadi pangan strategis untuk mendukung ketahanan pangan nasional (Karjadi, 2016)

Jika melihat luas panen kentang di Indonesia dari tahun 2015 - 2019 yaitu 66,983 ha, 66,450 ha, 75,611 ha, 68,683 ha dan 68,223 serta produktivitas kentang di indonesia dari tahun 2015 sampai 2019 yaitu 18.20 ton/ha 15.40 ton ha, 18.71 ton/ha dan 19.27 ton ha (Kementrian Pertanian Indonesia, 2019). planted in each of the two mulched potato beds (P2), faba beans were planted in each of the mulched potato beds (P3). potatoes with a monoculture system were planted on mulched beds (P4) and faba beans planted in one square bed without mulch (P5). The results showed that the highest potato yield was at $P$ but the results did not meet the standard for granola varieties, and the faba bean plant did not give results. The potato crop yields this way because at the time of tuber formation there is a disease attack, that attacks the leaves so that the photosynthesis tool is disturbed. The yield of faba beans is due to the influence of environmental temperature which does not support podformation.

Walaupun terjadi kenaikan produktivitas pada tahun 2019 tidak sebanding dengan permintaan kentang yang semakin meningkat pesat dimana dalam proyeksi akan meningkat 1,02 juta ton pada tahun 2020 (Syafa'at et al., 2006). Untuk dapat memenuhi permintaan akan kentang produktivitas kentang harus selalu ditingkatkan.

Dalam praktik pertanian, petani menggunakan pupuk kimia sintetis untuk meningkatkan hasil pertanian. Beberapa persoalan terjadi pada penggunaan dalam jangka yang lama, yaitu terjadi degradasi lahan karena penggunaan yang berlebihan sehingga hasil pertanian akan terus menurun. Namun ada praktik pertanian yang mudah diterapkan oleh petani untuk menggantikan pupuk sintetis yaitu tumpangsari dengan tanaman jenis legum. Dimana tanaman jenis legum mampu menambat nitrogen bebas menjadi tersedia bagi tanaman dan ada kemungkinan dapat menyumbang nitrogen tersebut ke tanaman lain. Sehingga input pupuk oleh petani 
berkurang dan degradasi lahan dapat ditekan (Anil et al., 1998)

Tempat hidup kentang baik pada daerah dataran tinggi atau pegunungan yaitu dengan ketinggian lebih dari 700 mdpl (Samadi, 2007). Tanaman legume yang tempat hidupnya mirip dengan kentang adalah kacang faba (Vicia faba L) atau sebutan masyarakat dieng adalah kacang babi. tanaman kacang faba sama seperti tanaman legume yang mampu menyumbang nitrogen. Tetapi belum ada penelitian tentang pengaruh model tumpangsari kacang faba dengan kentang terhadap hasil kentang. Sehingga penulis ingin mengetahui hasil tanaman pada beberapa model penanaman kentang dan kacang faba.

\section{METODE}

Penelitian ini dilaksanakan pada bulan Februari 2020 sampai bulan Mei 2020, di Kebun Percobaan Fakultas Pertanian dan Bisnis UKSW Salaran, Kecamatan Getasan, Kabupaten Semarang (ketinggian 1500-1700 mdpl). Alat yang digunakan dalam percobaan adalah traktor, cangkul, dan kamera HP. Bahan yang digunakan adalah kentang varietas granola, kacang faba khas dieng, pupuk kandang, pupuk ZA, pupuk urea, pupuk Fertiphos, pupuk $\mathrm{KCl}$, pupuk hayati kedelai. Sebelum ditanam lahan ditraktor dan dibuat bedengan dengan panjang 2 meter, lebar 30 $\mathrm{cm}$, tinggi $30 \mathrm{~cm}$ dan jarak antar bedengan 30 $\mathrm{cm}$. Sistem tanam kentang mengacu pada Juknis (Diwa et al., 2015) dan sistem tanam kacang faba mengacu pada (Etemadi et al., 2019). Penelitian dilaksanakan dengan sistem pertanian nonorganik, yaitu tetap menggunakan pupuk kimia sintetik tetapi tanpa menggunakan pestisida sintetik untuk penanganan hama dan penyakit.

Penelitian ini adalah jenis penelitian ekploratif. Perlakuan dalam penelitian ini yaitu kentang dan kacang faba ditanam pada bedengan bermulsa dengan rasio 2:1 (P1), kacang faba ditanam pada setiap sela dua bedengan kentang bermulsa (P2), kacang faba ditanam pada setiap sela bedengan kentang bermulsa (P3), tanaman kentang dengan sistem monokultur yang ditanam pada bedengan bermulsa (P4) dan tanaman kacang faba yang ditanam pada satu bedengan persegi empat tanpa mulsa (P5). Hasil tanaman ditimbang pada umur 90 hari setelah tanam.

\section{HASIL DAN PEMBAHASAN}

Tabel 1. Produktivitas Tanaman

\begin{tabular}{lll}
\hline Perlakuan & $\begin{array}{l}\text { Produktivitas } \\
\text { Kentang } \\
\text { (ton/ha) }\end{array}$ & $\begin{array}{l}\text { Produktivitas } \\
\text { kacang faba } \\
\text { (ton/ha) }\end{array}$ \\
\hline P1 & 6.296 & 0.000 \\
P2 & 6.556 & 0.000 \\
P3 & 4.889 & 0.000 \\
P4 & 5.815 & 0.000 \\
P5 & 0.000 & 0.000 \\
\hline
\end{tabular}

Hasil Produktivitas tanaman kentang pada penelitian ini sangat rendah bahkan sangat jauh dari standar varitas yang mencapai 26,5 ton/ha. Rendahnya produktivitas tanaman kentang ini dipengaruhi oleh lingkungan lahan penelitian yang merupakan daerah endemik jamur Phytophthora infestans adapun gagal produktivitas yang rendah dipengaruhi dikarenaan ditanam terjadi serangan penyakit yang diduga penyakit busuk daun (gambar 1) yang disebabkan oleh jamur Phytophthora infestans dan penyakit layu bakteri (gambar 2) disebabkan oleh Ralstonia solanacerum. 
Menurut Yulimasni (2003), ciri-ciri penyakit busuk daun adalah bercak-bercak kecil berwarna hijau kelabu dan agak basah hingga warnanya berubah jadi warna coklat sampai hitam. Untuk ciri-ciri busuk bakteri adalah daun muda pada pucuk tanaman layu dan daun bagian bawah menguning (Hartati et al., 2016). Menurut informasi dari petani kentang di daerah sekitar lahan penelitian, daerah lahan penelitian adalah daerah endemik penyakit busuk daun. Kondisi tersebut mengakibatkan hasil umbi tanaman kentang tidak berkembang karena kehilangan alat untuk fotosintesis.

Menurut Boudreau (2013), Peningkatan penyakit tanaman pada sistem tumpangsari bisa saja di sebabkan oleh kepadatan tanaman dalam suatu areal. Dengan bertambah padatnya tanaman, iklim mikro areal pertanaman mendukung untuk berkembangnya patogen di areal tersebut. Seperti diketahui jika patogen jenis jamur akan berkembang dengan baik pada kelembaban tinggi, sehingga dalam tumpangsari infeksi jamur akan meningkat karena lingkungan yang sangat mendukung serta didukung oleh curah hujan yang tinggi dan kelembaban udara wilayah yang tinggi. Serangan bakteri bisa saja karena tanaman kentang tersebut kelebihan hara nitrogen (Senoaji dan Praptana, 2013), karena adanya penambahan hara dari tanaman legum yang dapat mengubah nitrogen bebas menjadi tersedia. Karena jika tanaman kelebihan hara nitrogen terjadi perubahan metabolisme tanaman karena aktivitas beberapa enzim kunci seperti fenol menurun, kadar fenolat dan lignin yang termasuk dalam sistem pertahanan tanaman terhadap infeksi suatu pathogen menjadi rendah yang akhirnya tanaman lebih mudah diserang bakteri.

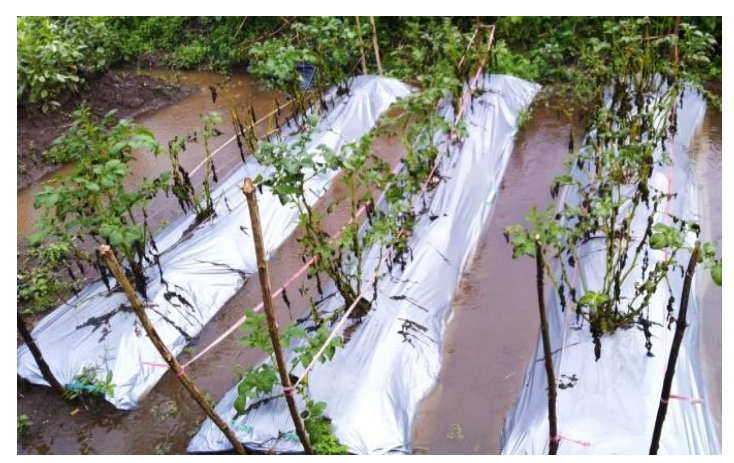

Gambar 1. kondisi tanaman kentang yang terserang penyakit busuk daun

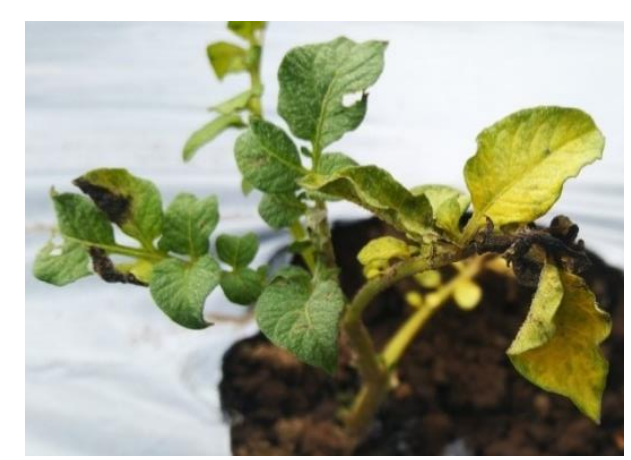

Gambar 2. kondisi tanaman yang terserang penyakit layu bakteri

Kondisi tanaman kacang faba pada penelitian ini tidak menghasilkan polong sama sekali. Pada fase pertumbuhan kacang faba memperlihatkan kondisi yang baik sampai pada saat berbunga. Setelah bunga kacang faba mekar sempurna, semua bunga membusuk dan berwarna hitam selanjutnya akan gugur dan diikuti oleh daun. Gagalnya kacang babi saat berbunga bukan disebabkan oleh penyakit tanaman tetapi. Diduga hal ini karena lahan tempat penelitian memiliki suhu yang tinggi dari suhu tempat asal tanaman, suhu lahan penelitian yaitu $17,5^{\circ} \mathrm{C}-29,8^{\circ} \mathrm{C}$ dan suhu dieng yaitu $12^{\circ} \mathrm{C}-20^{\circ} \mathrm{C}$. Penelitian (Etemadi $e t$ al., 2019) menyatakan pada suhu tinggi dapat menyebabkan gugurnya bunga dan polong kacang faba. 


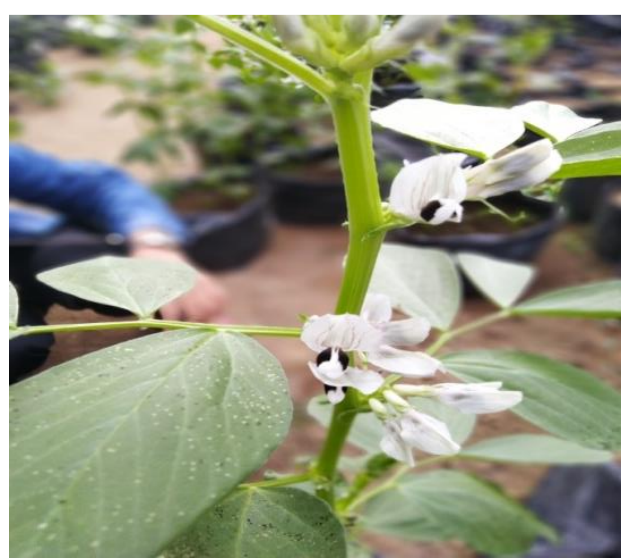

Gambar 3. kondisi tanaman kacang faba saat berumur 40 hari

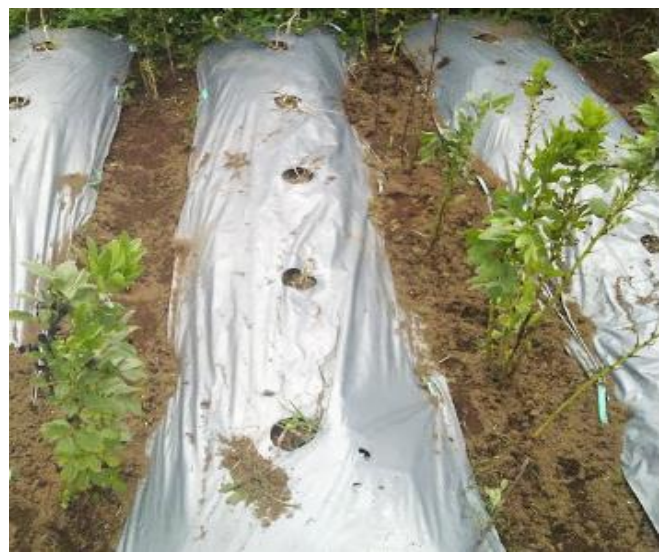

Gambar 4. kondisi tanaman kacang faba saat berumur 60 hari

\section{KESIMPULAN DAN SARAN}

Dari penelitian yang dilakukan diperoleh kesimpulan pada P2 menunjukkan hasil kentang yang paling tinggi, dan urutan hasil produktivitas kentang tertinggi dari P1 sampai P5 adalah 6.296 ton/ha 6.556 ton/ha 4.889 ton/ha 5.815 ton/ha dan 0.000 ton/ha tetapi karena serangan penyakit hasil semua perlakuan tidak memenuhi standar varietas yang mencapa 26,5 ton/ha. Tanaman kacang faba pada penelitian ini tidak menghasilkan sama sekali karena pengaruh dari lingkungan tempat penelitian yang bersuhu lebih tinggi dibandingkan dataran tinggi Dieng.

Saran dari penelitian selanjutnya adalah perlu diperhatikan status lahan tempat penelitian apakah endemik penyakit tanaman kentang atau tidak.

\section{DAFTAR PUSTAKA}

Anil, L. J. Park, R.H. Phipps \& A .Miller. (1998). Temperate intercropping of cereals for forage: A review of the potential for growth and utilization with particular reference to the UK. Grass and Forage Science. 53(4), pp. 301$317 . \quad$ doi: 10.1046/j.13652494.1998.00144.x.

Boudreau, M. A. (2013). Diseases in intercropping systems. Annual Review of Phytopathology. 51(February), pp. 499519. doi: 10.1146/annurev-phyto$082712-102246$.

Diwa, T. A., Dianawati, M. \& Sinaga, A. (2015). Petunjuk Teknis Budidaya Kentang.

Etemadi, F., M. Hashemi. A. V. Barker. O. R. Zandvakili \& Xiaobing. (2019) Agronomy, Nutritional Value, and Medicinal Application of Faba Bean (Vicia faba L.). Horticultural Plant Journal, 5, pp. 170-82.

Hartati, S. Y., E. Hadipoentyanti. Amalia \& Nursalam. (2016). Skrining Ketahanan Somaklon Nilam Terhadapp Penyakit Layu Bakteri (Ralstonia solanacearum). Jurnal Penelitian Tanaman Industri, p. $131 . \quad$ doi: 10.21082/littri.v21n3.2015.131-138.

Indonesia, K. pertanian. (2019). Produktivitas Kentang Menurut Provinsi, Tahun 20152019. Available at: https://www.pertanian.go.id/home/?sho $\mathrm{w}=$ page $\&$ act $=$ view $\& \mathrm{id}=61$.

Karjadi, A. (2016). Produksi Benih Kentang (Solanum tuberosum, L.). Balai Penelitian Tanaman Sayuran. Badan Penelitian dan Pengembangan Pertanian. Kementerian Pertanian.

Kolasa, K. (1993). The Potato and Human Nutrition. Am. Potato J, 70(5), pp. 375383.

Samadi, B. (2007). Kentang dan Analisis 
Usaha Tani. Yogyakarta: kanisius.

Senoaji, W. \& Praptana, R. H. (2013). Interaction between Nitrogen and Tungro Disease Incidence and Its Integrated Control in Rice. Iptek Tanaman Pangan, 8(2), pp. 80-89.

Syafa'at, N., Hadi, P. U. \& Purwoto, A. (2006). Proyeksi Permintaan dan Penawaran Komoditas Hortikuktura Utama Pertanian, 2005-2020. Sadra, Dewa ketut Frans B.D Situmorang Jefferson, 15(46), pp. 21-40.

Yulimasni. (2003). Serangan Penyakit Busuk Daun (Phytophtora Infestans Mont De Barry) Pada $14 \mathrm{Klon} /$ Varietas Unggul Kentang Di Alahan Panjang Sumatera Barat. Balai Pengkajian Teknologi Pertanian, pp. 181-185. Available at: http://sumbar.litbang.pertanian.go.id/ima ges/pdf/hptkentang.pdf. 